\title{
Student Mistakes in "Algebraic Forms" and Their Relationship to the Ability of Teachers and Prospective Mathematics Teachers
}

\author{
Yumiati ${ }^{1, *}$ and Saleh Haji ${ }^{2}$ \\ ${ }^{1}$ Lecturer at the Mathematics Education Study Program, Universitas Terbuka, Indonesia \\ ${ }^{2}$ Lecturer at the Mathematics Education Study Program, Universitas Bengkulu University \\ ${ }^{*}$ Corresponding author. Email: yumi@ecampus.ut.ac.id
}

\begin{abstract}
This study aims to determine students' mistakes in solving math problems on the topic 'Algebraic Forms' and their relation to the ability of teachers and prospective mathematics teachers. This type of research is descriptive quantitative. This research sample was 116 students of class 8 SMP in Pamulang district, South Tangerang city, while the teachers and prospective mathematics teachers were 37 people. The results of the study showed that the mistakes made by the students were in the form of 1) $23 \%$ misconception; 2) $14 \%$ errors of algebraic operations; 3) 9\% errors due to carelessness; 4) the students' ability towards the topic of algebraic forms in the medium category; 5) the ability of teachers and prospective mathematics teachers to be in a good category, and 6) The contribution of the ability of teachers and prospective mathematics teachers to students' mathematics abilities is in the medium category.
\end{abstract}

Keywords: Student mistakes, Prospective mathematics teachers, Ability of teachers.

\section{INTRODUCTION}

Mathematical skills of school students in Indonesia at the primary to secondary school levels are still low. The math ability score of students in Indonesia was 379, $71^{\text {st }}$ ranking out of 78 countries globally, and participants of the Program for International Student Assessment (PISA) [1]. Mathematical problems on PISA contain problems whose solution requires a comprehensive understanding of mathematical concepts. Also, solving these problems requires creativity in developing mathematical concepts following the problems contained in the problems. Students' mistakes are caused by their lack of understanding of related concepts, and are not skilled in managing the concepts they know to solve problems.

Generally, students have the most algebra errors in terms of a) manipulating algebraic operations, b) changing the subject of formulas, c) factoring algebraic terms, and d) solving quadratic equations. Another factor is the students' carelessness and lack of confidence in answering questions [2]. Carelessness in solving math problems is a mistake that often occurs for students. This carelessness is the result of his haste in solving a problem. This is due to the limited time provided for solving questions or other needs of students. Likewise, the attitude of distrust of students towards teachers makes students not serious in solving a math problem. This student's lack of seriousness can make mistakes in solving a problem. Other student mistakes in algebra are basic misconceptions and the relationship among concepts [3]. The basic concept as a prerequisite concept needed to solve a problem is very necessary because mathematics is the knowledge that is built on the relationship between concepts.

Students' mistakes or difficulties in algebra can affect solving problems in other mathematical concepts [4]. Various attempts have been made to overcome student weaknesses in algebra, including through curriculum improvement [5]. An effective curriculum can clarify the material and teaching approaches needed to achieve the goals of learning mathematics. Clarity of material, teaching approaches, learning media, and learning resources can help teachers and students carry out effective learning so that students' mistakes can be avoided in solving math problems.

A mistake is something wrong, wrong action [6]. Errors in mathematics can be in the form of mistakes in understanding and using mathematical facts that are not 
correct. As the use of symbols ' $\forall$ ' (for all), it is used not for all. Another example, student error using the Pythagorean theorem for solving a problem of nonsquare triangles.

Mathematics learning errors, consisting of errors in a. facts, b. concept, c. principles, and d. operation [7]. Fact errors are errors in the use of facts that are not according to what they should be. Concept errors are mistakes in understanding or using a concept in a new situation. Principle errors are errors in connecting inappropriate concepts. Operation errors are errors in performing mathematical procedures and calculations.

The factors that cause students' mistakes in learning mathematics consist of internal and external factors [8]. Internal factors exist in students themselves, such as anxiety, perceptions, motivation, and student health. External factors are outside of students, such as curriculum, teachers, teaching models/approaches, media, and learning resources. Internal factors include the psychological condition and motivation of students [9]. External factors include the competence of teachers and prospective mathematics teachers who teach in schools. Teacher competence is the knowledge, skills, and attitudes shown in the intelligent and responsible behavior that a teacher has in carrying out his profession [10]. Competence consists of pedagogic, personality, social, and professional competencies. Pedagogic competency is an ability that teachers must have about student characteristics seen from various moral, emotional, and intellectual [11]. The pedagogical competence of teachers and prospective mathematics teachers is the mastery of mathematics material, learning, and student development.

Therefore the research was conducted in order to explore: 1) How the mistakes were made by the students in solving math problems on the topic of Algebraic Forms 2) the ability of mathematics teachers and prospective teachers to mathematics

\section{METHOD}

This type of research is descriptive quantitative. Descriptive quantitative research is concerned with collecting data to provide an overview or affirmation of a concept or symptom and answer questions regarding a current research subject [12]. This study's participants were 116 students of grade 8 SMP in Pamulang District, South Tangerang City. Meanwhile, there were 37 teachers and prospective mathematics teachers. The research instrument was an essay test on the algebraic form, which consists of 8 items. All items were valid with a calculated $\mathrm{r}$-value greater than $\mathrm{r}$ table $=0.334$. The reliability of the instrument 0.883 (Cronbach Value).

\section{RESULTS AND DISCUSSION}

Based on the result of the analysis, students' ability on algebraic forms was 18.65 out of 55 (maximum score). This ability was included in the 2nd quartile (Q2), which is moderate. The mistakes made by students were as follows.

\subsection{Mathematical Misconceptions}

The types of errors in solving these problems were as follows:

$$
\begin{aligned}
\left(2 a^{2}-3 a+4\right)+\left(6 a^{2}+4 a\right) & =2 a^{2}-6 a^{2}-3 a+4 a+4 \\
& =-4 a^{2}-7 a+4
\end{aligned}
$$

The type of mistake made was a misconception about the form addition of like terms. Error linking term $(-3 a)$ with term $(4 a)$. Students view the term $4 a$ as a negative number, so that the sum with the term $-3 a$ results in the term $-7 a$. Mathematical concept errors made by students were $23 \%$.Besides, students made carelessness. The $6 \mathrm{a}^{2}$ term in the problem changes to $6 a^{2}$.

\subsection{Errors in Algebraic Operations}

Errors in algebraic operations, namely:

$$
\begin{aligned}
& -3 a+4=-7 a \\
& 6 a^{2}+4 a=10 a^{2} \\
& 2 a^{2}-7 a=-5 a^{3} \\
& -5 a^{3}+10 a^{2}=-15 a^{5} .
\end{aligned}
$$

Since the terms are not the same, the terms cannot be operated. The errors of operating the algebraic form by students were $14 \%$.

$$
\begin{aligned}
& \text { 1. }\left(2 a^{2}-3 a+4\right)+\left(6 a^{2}+4 a\right) \\
& =\left(2 a^{2}-7 a\right)+\left(10 a^{2}\right) \\
& =-5 a^{3}+10 a^{2} \\
& =-15 a^{5}
\end{aligned}
$$

\subsection{Mistakes Due to Carelessness}

The careless mistake of rewriting the following polynomial division result, $\frac{2(x+2)(x+1)}{(x+2)}$ should equal $2(x+1)$. However, students solve it to be $\frac{2(x+1)}{2(x+2)}$. The errors due to carelessness by students were $9 \%$.

$$
\begin{aligned}
& \frac{4 u^{2}+12 u+8}{u x+4} \\
& \frac{{ }^{2}-4\left(u^{2}+3 u+2\right)}{u(u+2)} \quad \therefore 2 \times \cdots: 2^{2} \\
& \frac{22(x+2)(x+1)}{(x+2)}: \frac{2(x+1)}{2(x+2)}
\end{aligned}
$$


One of the causes of students' mistakes comes from external factors, namely the competence of teachers and prospective mathematics teachers [10]. Teachers who are less skilled in explaining a mathematics concept make it difficult for students to understand the concept. Likewise, teachers who are less competent in explaining a counting operation will make students less skilled in performing arithmetic operations [13]. This shows a relationship between students' difficulties in understanding the material and solving math problems with the ability of teachers and prospective mathematics teachers [14]. Students' errors in mathematics can also be caused by students' views on teachers in managing their mistakes [15].

The tests' results on the ability of teachers and prospective mathematics teachers to mathematics material are presented in the following table.

Table 1. The abilities of teachers and prospective mathematics teachers

\begin{tabular}{ll}
\hline Statistics & Value \\
\hline Highest (14) & 21 \\
Lowest (0) & 0 \\
Average & 9.78 \\
Standard deviation & 5.24 \\
\hline
\end{tabular}

From the table, it can be seen that the ability of teachers and prospective mathematics teachers is 9.78 out of 14. This ability is in the 3rd quartile (Q3), the good category. This shows that the contribution of teachers and prospective mathematics teachers' ability to students' abilities is in the medium category.

The following shows the results of the work of teachers and prospective mathematics teachers in solving math problems.

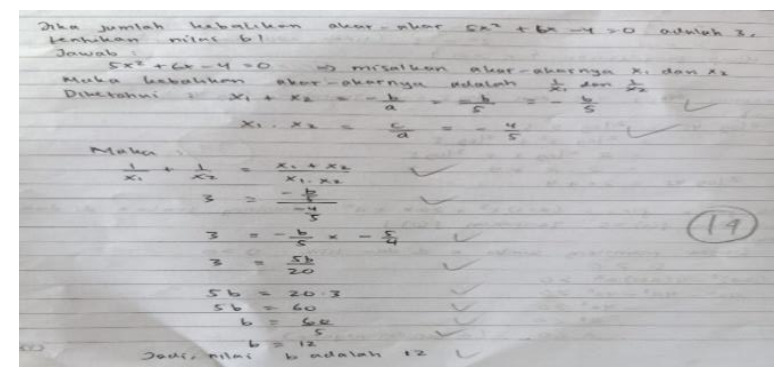

Figure 1. Problem-solving by teachers and prospective mathematics teachers

In the figure, it appears that the respondent understands various concepts, namely: the concept of inverse roots of $\frac{1}{x_{1}}$ and $\frac{1}{x_{2}}$, the concept of the fraction of the algebraic form $\frac{1}{x_{1}}+\frac{1}{x_{2}}=\frac{x_{1}+x_{2}}{x_{1} x_{2}}$, and the concept of quadratic equations. The ability of teachers and prospective teachers have an impact on students' abilities and minimizes student difficulties in solving math problems.

\section{CONCLUSION}

It can be concluded that 1) there were $23 \%$ of misconception; 2) The operating error of the algebraic form was $14 \%$; 3) Errors which happened due to carelessness were $9 \%$; 4) the ability of algebraic forms of the students were in the medium category; 5) the ability of the teachers and the prospective mathematics teachers were in a good category and 6) The contribution of the ability of teachers and prospective mathematics teachers to students' mathematics abilities is in the medium category.

\section{ACKNOWLEDGMENTS}

Our gratitude goes to the teachers and principals of SMP NegeriPamulang District, South Tangerang City. For the help in the success of the research.

\section{REFERENCES}

[1] OECD. 2018. PISA Result in Focus. http://www.oecd.org/pisa/pisa-2015-results-infocus.

[2] N. Yahya, M.Shahrill, 2015. The strategies used in solving algebra by secondary school repeating students. Social and Behavioral Sciences 186, 2015, 1192-1200.

[3] O'Brien, A. \& Ni, Riordain, M., 2017. Examining difficulties in initial algebra. European Society for Research in Mathematics Education.

[4] Widodo, S.A., Prahmana, R.C.I, Purnami, A.S., 2017. Teaching materials of an algebraic equation. Journal of Physics: Conference Series, 934(1), 012017

[5] Straus, M., 2020. Some strengths and weaknesses in algebra achievement of Slovene eighth-grade students. Studies in Mathematics Education 29 (2003) 207-226.www.elsivier.com/stueduc.

[6] Depdikbud, 1999. Evaluasi Belajar . Jakarta: Dirjen Dikdasmen.

[7] Soedjadi, R. 2000. KiatPendidikanMatematika di Indonesia. Jakarta: DirjenDikti.

[8] Natalia, 2016. Analisis kesalahan siswa dalam mengerjakan soal-soal pada materi operasi bentuk aljabar kelas VIIIB SMP Pangudi Luhur I Klaten. Yogyakarta: FKIP, USD.

[9] Arwas, E., Flum, H., 2020. Pushing me ahead before I was ready was a serious mistake!. School memories and identity development. International 
Journal of Educational Research, Volume 103, 2020, 101649.

[10] Novauli, F. 2015. Kompetensi guru dalam peningkatan prestasi belajar pada SMP Negeri dalam kota Banda Aceh. Jurnal Administrasi Pendidikan Pasca sarjana Universitas Syiah Kuala, Volume 3, No. 1, Februari 2015.

[11] Undang-Undang RI Nomor 14 Tahun 2005 tentang Guru danDosen.

[12] Sugiyono2010. Metode Penelitian Kuantitatif , Kualitatif, dan R \& D. Bandung: Alfabeta.

[13] Komponen, T., Aunola, K., Nurmi, J.E., 2019. Verbal counting skill predicts later math. Performance and difficulties in middle school. Contemporary Educational Psychology, Volume 59, October 2019, 101803.

[14] Perera, H.N., John, J.E. 2020. Teachers' selfefficacy beliefs for teaching math: Relations with the teacher and student outcomes. Contemporary Educational Psychology, Volume 61, April 2020, 101842.

[15] Bleses, D., Jensen, P., Slot, P., Justice, L. 2020. Low-cost teacher-implemented intervention improves toddlers' language and math skills. Early Childhood Research Quarterly, 53(2020) 64-76. 